\title{
Productive and vegetative behavior of olive cultivars in super high-density olive grove
}

\author{
Primo Proietti ${ }^{1}$, Luigi Nasini ${ }^{1}$, Lara Reale ${ }^{*}$, Tiziano Caruso ${ }^{2}$, Francesco Ferranti ${ }^{1}$
}

'University of Perugia/ Dept. of Agricultural, Food and Environmental Sciences - Via Borgo XX Giugno, 74 - 06121

- Perugia - Italy.

2University of Palermo/Niale delle Scienze - Dept. of Agricultural and Forest Sciences, Building 490128 -

Palermo - Italy.

*Corresponding author <lara.reale@unipg.it>

Edited by: Francesco Montemurro

Received February 03, 2014

Accepted May 28, 2014
ABSTRACT: In recent years, there has been an increase in interest in super high-density (SHD) olive (Olea europaea L.) groves because they offer early entry into production, increased productivity and the possibility of using modified mechanical vine harvesters. This study was carried out in a young SHD olive grove to examine vegetative, histo-anatomical and productive characteristics and oil quality of the Spanish Arbequina and Italian Maurino and Leccino cultivars, characterized by low, low-to-medium and high vigor, respectively. Arbequina had low vigor and limited development in height and width, as well as a high leaf/wood ratio. Maurino had a canopy volume similar to that of Arbequina and, despite a great tendency to grow in height, had low vigor, a rather compact vegetative habitus, but good lighting in the canopy and high production efficiency. In Maurino, a greater palisade parenchyma height and a larger exposed lateral surface area of the palisade parenchyma cells were observed. In the fourth year after planting, fruit production of Arbequina was about $30 \%$ less than Leccino and Maurino. The oil content on a dry weight basis was slightly higher in Arbequina and Maurino than in Leccino. Oil quality was good for all cultivars. Keywords: canopy architecture, leaf anatomy, leaf area index, oil quality

\section{Introduction}

Olive (Olea europaea L.) is one of the most widespread fruit tree species in regions with a Mediterranean climate, reaching 9.5 Mha worldwide in 2010 (FAO, 2012). Both in traditional and nontraditional areas, interest has been increasing in super high-density (SHD) olive groves because they offer early entry into production, increases in productivity and the possibility of using continuous a straddle harvester that rides over the tree canopy (hedgerow) (De La Rosa et al., 2007; Tous et al., 2010). These advantages are responsible for the rapid spreading of this type of olive cultivation system in all olive-growing countries (Tous et al., 2003; Tous et al., 2010). However, there is still very little information available about the response of cultivars where this system has been adopted (Arbequina, in particular) to the specific climatic and cultural conditions of central Italy, which may differ from those of origin (Allalout et al., 2009; Godini et al., 2011). Furthermore, there is little information on adaptation of local cultivars to this new cultivation system (Camposeo et al., 2008; Proietti et al., 2011).

In this context, it is very important to study the behavior of cultivars grown under the SHD system. In particular, productive and vegetative characteristics in olive trees strongly respond to light availability in the crown, which is influenced by canopy size and the architecture of different cultivars (Cherbiy-Hoffmann et al., 2013; Schneider et al., 2012).

Considering that information is scarce about tree growth and productivity in different vigor cultivars grown under the SHD system, this study was carried out in a super high-density olive grove to compare canopy architecture, distribution of leaf area and light in the canopy, the leaf histo-anatomical characteristics, and the production efficiency and oil quality of the Spanish Ar- bequina and the Italian Leccino and Maurino cultivars. Arbequina, a low vigor cultivar, is currently considered the most important cultivar for super high-density olive groves (De La Rosa et al., 2007; León et al., 2007; Tous et al., 2010). Leccino and Maurino were chosen since they are cultivars characterized by high and low-to-medium vigor, respectively.

\section{Materials and Methods}

\section{Plant material}

The trial was carried out in central Italy (Deruta - about $350 \mathrm{~m}$ a.s.1., $12^{\circ} 41^{\prime} \mathrm{E}$ longitude, 42 ${ }^{\circ} 96^{\prime} \mathrm{N}$ latitude), in the third (2009) and fourth (2010) year after planting of an SHD olive grove, on trees of Arbequina, Leccino and Maurino cultivars, trained to the central axis system and spaced $4.5 \times 1.5 \mathrm{~m}$ /about 1,480 trees $\left.\mathrm{ha}^{-1}\right)$. The experiment was designed as a randomized block with tree blocks, each containing three adjacent rows per each cultivar. In each block five trees in the middle part of the central row for each cultivar were monitored, while the others ones served as "guard tree" borders.

The climate of the area is characterized by mild winters and warm and dry summers, with an average rainfall of 692 and $842 \mathrm{~mm}$ per year, in 2009 and 2010, respectively, mainly distributed in autumn and winter. The soil is medium textured and was kept under clean cultivation throughout the entire growing season. The trees had never been pruned, with the exception of eliminating the branches on the basal part of the stem (up to $50 \mathrm{~cm}$ in height) to allow for mechanical soil management and harvesting with a modified vine harvester. From mid-July to mid-Sept, supplementary irrigation was applied about every three days using drip lines (total amount of irrigation water was about $200 \mathrm{~m}^{3}$ $\mathrm{ha}^{-1}$ per year). The olive grove was fertilized by spread- 
ing $200 \mathrm{~kg} \mathrm{ha}^{-1}$ of urea $(46 \% \mathrm{~N})$ and $100 \mathrm{~kg} \mathrm{ha}^{-1}$ of complex fertilizer (8-24-24 N-P-K) on the soil in the first ten days of May and $100 \mathrm{~g}$ per tree of ammonium nitrate $(34 \% \mathrm{~N})$ during the first ten days of July.

\section{Vegetative characteristics}

In 2009 and 2010, the height of the tree, the average diameter of the stem at $20 \mathrm{~cm}$ from the ground, the height $(\mathrm{h})$ and the average radius $(\mathrm{r})$ of the canopy (calculated as the average of the radius of the basal, middle and apical parts of the canopy, both within the row and in the direction perpendicular to it) and the volume of the canopy $\left(\mathrm{V}=\pi \times \mathrm{r}^{2} \times \mathrm{h}\right)$ were determined for 15 trees per cultivar. The number, length, basal diameter and inclination to the vertical of primary and secondary branches were also determined. On shoots of five branches per tree, the average length, number of nodes and internode length were measured.

\section{Leaf area index (LAI) and light distribution in the canopy}

The LAI was calculated on six trees per cultivar at the beginning of Aug of 2009 and 2010 as the ratio between the total leaf area per tree and the projection of the canopy surface on the ground. For the same trees, the LAI was also determined in different portions of the canopy, as reported by Tombesi et al. (2000), by counting the number of leaves in contact with vertical bars placed on a horizontal grid $(10 \times 10 \mathrm{~cm})$ of the whole projection of the canopy. Using a leaf area meter, the total leaf area per tree was calculated at the beginning of Aug by determining the average leaf area of a sample of 200 leaves, collected randomly from six trees per cultivar, and multiplying the average leaf area by the total number of leaves per tree. The total number of leaves per tree was determined by counting the leaves, without detaching them, on the same six trees per cultivar.

The light distribution in the canopy was determined at the beginning of Aug at $11 \mathrm{~h} 00$ and $17 \mathrm{~h} 00$ by measuring the photosynthetic photon flux density (PPFD) in the canopy, using a Quantum/Radiometer/ Photometer", at 50, 100, 150 and, only for Maurino and Leccino, at $200 \mathrm{~cm}$ from the ground, at a distance of 30 $\mathrm{cm}$ from the stem, and at the four cardinal points.

Area dry mass (ADM), chlorophyll (Chl) content and histo-anatomical characteristics of the leaves

At the beginning of Aug 2010, for each cultivar, samples of one-year-old leaves were transferred to the laboratory in a portable refrigerator for the determination of leaf ADM, Chl content and histo-anatomical characteristics. From 90 leaves (six per tree) per cultivar, discs $\left(1.13 \mathrm{~cm}^{2}\right.$ each) with a representative color of the whole blade were removed and ADM, Chl a and Chl b contents were determined. To determine ADM (leaf dry weight/leaf area), for each cultivar 90 discs were dried to constant weight in a forced air oven at $90{ }^{\circ} \mathrm{C}$. Leaf $\mathrm{Chl}$ contents were determined for fifteen leaves per cultivar according to Lichtenthaler and Wellburn (1983).

To study the histo-anatomical characteristics, small portions of leaf lamina (about $4 \mathrm{~mm}^{2}$ ) were collected from 30 leaves per cultivar. Samples were fixed in $5 \%$ glutaraldehyde in $0.075 \mathrm{M}$ sodium cacodylate buffer, $\mathrm{pH}$ 7.2 , and post-fixed in $1 \%(\mathrm{w} / \mathrm{v}) \mathrm{OsO}_{4}$ in $0.075 \mathrm{M}$ sodium cacodylate buffer for $1.5 \mathrm{~h}$. Samples were then dehydrated in increasing concentrations of ethanol and embedded in resin (Epon, 2-dodecenylsuccinic anhydride and methyl nadic anhydride mixture) (Reale et al., 2009). Semi-thin sections (1-2 $\mu \mathrm{m})$ were cut with an ultramicrotome equipped with a glass blade, stained with toluidine blue and observed under a light microscope. The thickness of the leaf lamina and palisade parenchyma, the size and number of palisade cells per $\mathrm{mm}^{2}$ of lamina, and the number and guard cell length of stomata were determined using image analysis software Leica IM 1000 (Leica, Cambridge, UK).

\section{Productive characteristics and oil quality}

The total production of olives per tree (15 trees per cultivar) at harvesting (done at the end of Oct of 2009 and 2010) was determined. Harvesting was carried out when the olives reached a Jaén index score of about 2.5, 3.5 and 4.0 for Arbequina, Leccino and Maurino, respectively. From the total production, production efficiency was calculated by expressing production over both the stem cross sectional area and the leaf area per tree. Fruit weight and water and oil content (by NIR: Near Infra Red on three samples of olives per cultivar) were determined. Oil chemical characteristics (acidity, peroxide number, total phenol content and fatty acid composition) and sensory evaluation (panel test) were carried out following the Official Methods of Analysis (Reg. EU N. 61/2011) on oils extracted using an artisanal mini olive mill one day after harvesting on three fruit samples of about $2.0 \mathrm{~kg}$ per cultivar, harvested from fifteen trees per cultivar.

\section{Statistical analysis}

Significance of the differences among the averages was determined by variance analysis using the StudentNewman-Keuls Test. The level of significance was determined as $p<0.05$. For each trait, the mean and standard errors were obtained.

\section{Results}

\section{Vegetative activity}

In the three cultivars examined, at the third and fourth year after planting of the olive grove, no differences were found in the total number of leaves per tree, which in the fourth year after planting was close to 12,000 (Table 1). The area of a leaf and, consequently, the total leaf area per tree of Maurino were lower than Arbequina and Leccino; although the differences between Leccino and Arbequina were not significant, 
Leccino had a higher leaf area and total leaf area per tree. The area of the stem cross-section of Leccino was greater than those of Maurino and Arbequina, which were no different from each another. The same results were obtained for the total volume of primary and secondary branches per tree (calculated from the number of branches per tree and their length and diameter), resulting in Maurino and Arbequina being about $50 \%$ of that of Leccino (data not shown).

The average tree height of Arbequina in the fourth year was lower $(p<0.05)$ compared to Leccino and Maurino $(176 \pm 11.2 \mathrm{~cm}, 239 \pm 12.1 \mathrm{~cm}$ and $252 \pm 9.7$ $\mathrm{cm})$, which were not different from one another. The shoot length was lower in Maurino than in Arbequina and Leccino, while the opposite was found for internode length (Table 2). In relation to the average branch length, no differences were found for primary branches among the three cultivars, whereas the secondary branches were shorter in Arbequina $(61 \pm 10.1 \mathrm{~cm})$ and longer in Maurino (about $82 \pm 9.5 \mathrm{~cm}$ ). The lateral development of Leccino, which in the fourth year had an average canopy diameter of $2.14 \pm 0.25 \mathrm{~m}$, mean \pm standard error, was higher $(p<0.05)$ than the other two cultivars (average diameter $1.35 \pm 0.19 \mathrm{~m}$, and $1.50 \pm 0.18 \mathrm{~m}$ for Maurino and Arbequina, respectively). This was due to the lower inclination of the primary branches to the vertical in Maurino $62^{\circ}$ versus about $80^{\circ}$ in Leccino and Arbequina) and to the shorter secondary branches in Arbequina compared to Leccino. The canopy volume was much higher in Leccino than the other two cultivars; in Maurino, despite the lesser lateral development, the canopy volume was similar to that of Arbequina due to the greater height.

\section{LAI and light distribution in the canopy}

The LAI of Maurino and Arbequina (about 2.5) was higher than that of Leccino (1.72) (Figure 1). Maurino had better light distribution in the canopy (average values of 758 and $590 \mu \mathrm{mol}$ photons $\mathrm{m}^{-2} \mathrm{~s}^{-1}$, in the morn- ing and afternoon respectively), compared to Leccino (635 and $600 \mu \mathrm{mol}$ photons $\mathrm{m}^{-2} \mathrm{~s}^{-1}$ ) and above all to Arbequina (538 and $490 \mu \mathrm{mol}$ photons $\mathrm{m}^{-2} \mathrm{~s}^{-1}$ ).

\section{ADM, Chl content and histo-anatomical character- istics of the leaves}

The total Chl content per unit leaf area was slightly lower in Maurino $\left(5.2 \pm 0.21 \mathrm{~g} \mathrm{~m}^{-2}\right)$ than in the other two cultivars (about $5.8 \pm 0.31 \mathrm{~g} \mathrm{~m}^{-2}$ and $6.0 \pm$ $0.25 \mathrm{~g} \mathrm{~m}^{-2}$, for Arbequina and Leccino, respectively). The ratio between $\mathrm{Chl} a$ and $\mathrm{Chl} b$ showed no differences between the three cultivars (data not shown). The leaf parenchyma was organized in palisade-like and spongy parenchyma, enclosed between two epidermises, which were highly diversified (Figure 2A). The adaxial epidermis consisted of isodiametric cells (Figure 2B), while the stomata apparatus of the abaxial epidermis was arranged randomly and interpositioned in star-shaped trichomes that covered the guard cells (Figure 2C).

The palisade-like parenchyma consisted of three layers of cells more or less cylindrical, positioned sideby-side and bordering the intercellular spaces, smaller than those of the spongy parenchyma. The cells of the spongy parenchyma switched from an isodiametric to an irregular shape. Vascular bundles were present in the mesophyll. The leaf lamina was thicker in leaves of Arbequina and less thick in leaves of Leccino (Table 3). The leaf ADM in Leccino was slightly lower than that of Arbequina and Maurino, which were no different from each other (data not shown). In Leccino the palisade parenchyma was not as high as in Maurino and Arbequina. The ratio between the height of the palisade parenchyma and the thickness of the leaf lamina was higher in Maurino than in Arbequina and Leccino.

There were also differences with regard to the size of the palisade cells. In Leccino the palisade parenchyma consisted of cells with small section (Table 3 and Figure 2D), while in Arbequina and Maurino, the cells

Table 1 - Leaf and tree characteristics in the Arbequina, Leccino and Maurino cultivars at the beginning of Aug of the fourth year after planting (means \pm standard error).

\begin{tabular}{|c|c|c|c|c|c|}
\hline Cultivar & Leaf number & Leaf area & Leaf area per tree & Stem cross-section area & Canopy volume \\
\hline & $n$ & $\mathrm{~cm}^{2}$ & $\mathrm{~m}^{2}$ & $\mathrm{~cm}^{2}$ & $\mathrm{~m}^{3}$ \\
\hline Arbequina & $11,964 \pm 452^{\mathrm{a}}$ & $4.49 \pm 0.48^{\mathrm{ab}}$ & $5.37 \pm 0.47^{a b}$ & $9.61 \pm 0.54^{\mathrm{a}}$ & $2.87 \pm 0.25$ a \\
\hline Leccino & $11,704 \pm 403^{a}$ & $5.19 \pm 0.26^{b}$ & $6.07 \pm 0.31^{b}$ & $16.75 \pm 0.74^{b}$ & $4.96 \pm 0.31^{b}$ \\
\hline Maurino & $11,664 \pm 380^{a}$ & $3.95 \pm 0.19^{\mathrm{a}}$ & $4.60 \pm 0.32^{\mathrm{a}}$ & $10.40 \pm 0.55^{\mathrm{a}}$ & $3.35 \pm 0.26^{a}$ \\
\hline
\end{tabular}

In each column, the means followed by different letters differ at $p \leq 0.05$.

Table 2 - Shoot characteristics in the Arbequina, Leccino and Maurino cultivars at the beginning of Aug (the data are the average of the third and fourth year after planting) (means \pm standard error).

\begin{tabular}{lccc}
\hline Cultivar & Shoot length & Nodes per shoot & Internode length \\
\hline & $\mathrm{cm}$ & $\mathrm{n}$ & $\mathrm{cm}$ \\
Arbequina & $21.1 \pm 2.2^{\mathrm{b}}$ & $10.5 \pm 0.87 \mathrm{~b}$ & $2.00^{\mathrm{b}} \pm 0.07^{\mathrm{a}}$ \\
Leccino & $22.5 \pm 2.0^{\mathrm{b}}$ & $11.4 \pm 0.81 \mathrm{~b}$ & $1.97 \pm 0.08^{\mathrm{a}}$ \\
Maurino & $16.1 \pm 2.1^{\mathrm{a}}$ & $7.0 \pm 0.9 \mathrm{a}$ & $2.30 \pm 0.09^{\mathrm{b}}$ \\
\hline
\end{tabular}

In each column, the means followed by different letters differ at $p \leq 0.05$. 


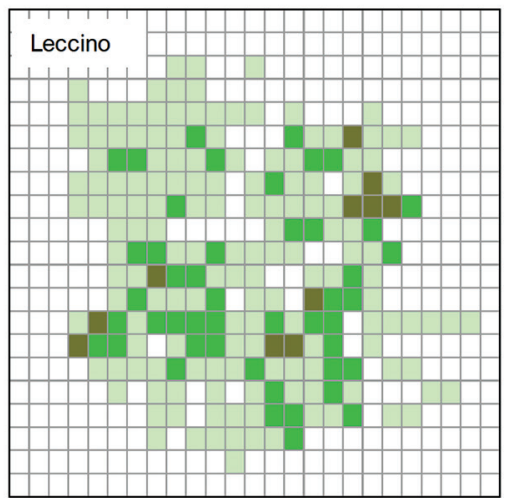

P

Leaf number
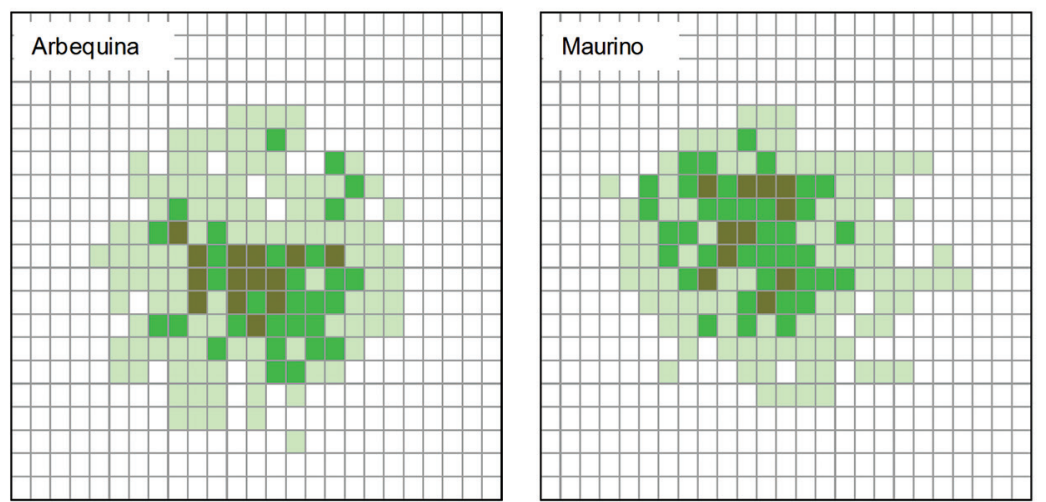

6-7 $\square$ 4-5 $\square$ 2-3 $\square 0-1$

Figure 1 - Distribution of leaves in the canopy of Arbequina, Leccino and Maurino cultivars (leaf number in $10 \times 10 \mathrm{~cm}$ horizontal grid of the whole projection of the canopy) at the beginning of Aug. The data are the average of the values obtained in the third and fourth year after planting. Cardinal points are indicated on the figures.
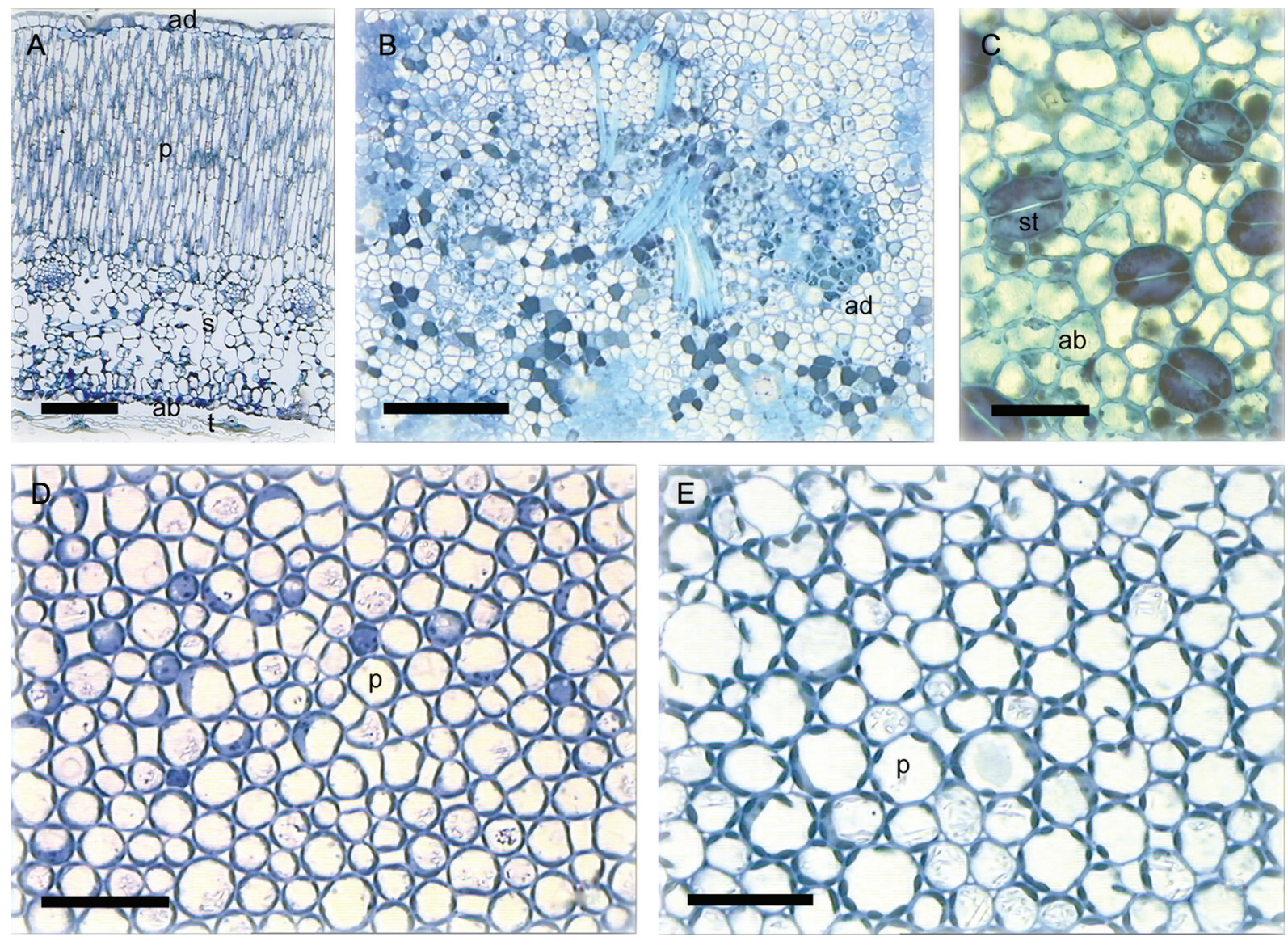

Figure 2 - Light microscopy images of olive leaves collected in July of the fourth year after planting: A Transversal semi-thin section of a leaf of Maurino in which it is possible to distinguish the two epidermises, palisade-like and spongy parenchyma, bar = $100 \mu$ m; $\mathbf{B}$ Tangential semi-thin section of the adaxial epidermis of a leaf of Arbequina, the isodiametric epidermal cells are evident, bar $=100 \mu \mathrm{m}$; $\mathbf{C}$ Tangential section of the abaxial epidermis of an Arbequina leaf with visible stomata apparatus, bar $=30 \mu \mathrm{m}$; D-E Tangential sections of palisade-like cells of leaves of Leccino (D) and Arbequina (E), bars $=30 \mu \mathrm{m}$. ab, abaxial epidermis; ad, adaxial epidermis; p, palisade-like cell; s, spongy parenchyma cell; st, stomata apparatus. 
had a longer diameter but there were no differences between them (Figure 2E). Consequently, the number of palisade cells per unit leaf area was higher in Leccino than in Arbequina and Maurino, which were no different from each other. The value obtained by multiplying the number of palisade cells per $\mathrm{mm}^{2}$ by the unit cell surface area showed that in Maurino the entire intercellular space was larger than in Arbequina and Leccino.

To estimate the exposed lateral surface of the palisade cells per unit leaf area, which is directly involved with gas exchange, the mean perimeter of the palisade parenchyma cells was multiplied by the height of the palisade parenchyma and by the number of palisade cells per unit leaf area. This gives the surface area through which $\mathrm{CO}_{2}$ enters the palisade cells. Leccino had the lowest exposed lateral surface area $(76.9 \pm 1.9$ $\mathrm{mm}^{2} \mathrm{~mm}^{-2}$ of leaf area). There were no differences between Arbequina and Maurino $\left(81.0 \pm 1.1 \mathrm{~mm}^{2} \mathrm{~mm}^{-2}\right.$ and $81.2 \pm 1.8 \mathrm{~mm}^{2} \mathrm{~mm}^{-2}$ of leaf area, respectively). The number of stomata per unit leaf area was the highest in Maurino and the lowest in Arbequina, while Leccino was intermediate (Table 4).

The lengths of the guard cells in Arbequina and Maurino were higher than in Leccino. Finally, the value obtained by multiplying the number of stomata per $\mathrm{mm}^{2}$ by the average length of their guard cells was longer in Maurino than in Leccino and Arbequina, between which there were no differences (Table 4).

\section{Productive characteristics and oil quality}

For all cultivars, fruit production began the third year after planting of the olive grove, with no difference between cultivars, production ranging from $0.2 \mathrm{~kg}$ per tree for Arbequina to about $0.5 \mathrm{~kg}$ per tree for the other two cultivars. In the fourth year after planting the olive grove, production per tree increased considerably (Table 5). Arbequina produced about $30 \%$ less fruit per tree than Leccino and Maurino, there being no difference between these two. Maurino had a higher production efficiency, based on the amount of production per unit of leaf area.

Fruit fresh weight was higher in Leccino than in Arbequina and Maurino (Table 6). Maurino had the highest fruit water content and Arbequina the lowest. The oil content on a dry weight basis was slightly higher in Arbequina and Maurino (about $36 \%$ ) than in Leccino (about $33 \%$ ). All the oil samples were extra virgin according to EU regulations, with free acidity and a peroxide number less than 0.3 and 7 , respectively (Table 7). Total phenol content of Maurino and Leccino was higher than that of Arbequina. All cultivars produced well-balanced oils with medium-high fruity values. Maurino oil was slightly more fruity, bitter and pungent than those of Arbequina and Leccino (Table 8).

In relation to the fatty acid composition, all the varieties had good nutritional value, with oleic acid greater than $71 \%$, linoleic and palmitic acids less than $10 \%$ and $15 \%$, respectively, and the oleic/linoleic acid ratio greater than 7 and higher in Leccino than in the

Table 3 - Histo-anatomical characteristics in the Arbequina, Leccino and Maurino cultivars at the beginning of Aug of the fourth year after planting (means \pm standard error).

\begin{tabular}{|c|c|c|c|c|c|}
\hline Cultivar & Lamina thickness & Palisade height & Percentage of palisade & Palisade cell size & Number of palisade cells \\
\hline & & & $\%$ & $\mu \mathrm{m}^{2}$ & $\mathrm{n} \mathrm{mm}^{-2}$ \\
\hline Arbequina & $616.3 \pm 9.4^{b}$ & $293.0 \pm 5^{b}$ & $47.6 \pm 1^{\mathrm{a}}$ & $115.8 \pm 3.9^{b}$ & $7,365.8 \pm 120^{a}$ \\
\hline Leccino & $503.0 \pm 1.7^{a}$ & $248.5 \pm 1^{\mathrm{a}}$ & $49.4 \pm 1.83^{a}$ & $95.9 \pm 2.4^{\mathrm{a}}$ & $8,942.3 \pm 347^{b}$ \\
\hline Maurino & $582.3 \pm 26.6^{b}$ & $299.9 \pm 14.8^{b}$ & $51.6 \pm 0.1^{b}$ & $115.8 \pm 10.1^{b}$ & $7,054.6 \pm 179^{a}$ \\
\hline
\end{tabular}

In each column, the means followed by different letters differ at $p \leq 0.05$.

Table 4 - Density and size of the stomata in the Arbequina, Leccino and Maurino cultivars at the beginning of Aug of the fourth year after planting.

\begin{tabular}{lccc}
\hline Cultivar & Length of the guard cells & Number of stomata & Length of the guard cells $\times \mathrm{N}^{\circ}$ of stomata \\
\hline & $\mu \mathrm{m}$ & $\mathrm{mm}^{-2}$ & $\mathrm{~mm} \mathrm{~mm}^{-2}$ \\
Arbequina & $24.50 \pm 0.4^{\mathrm{b}}$ & $425.37 \pm 8.3^{\mathrm{a}}$ & $10,42 \pm 0.5^{\mathrm{a}}$ \\
Leccino & $22.98 \pm 0.4^{\mathrm{a}}$ & $454.90 \pm 4.4^{\mathrm{b}}$ & $10,45 \pm 0.5^{\mathrm{a}}$ \\
Maurino & $25.03 \pm 0.3^{\mathrm{b}}$ & $470.75 \pm 8.6^{\mathrm{c}}$ & $11,78 \pm 0.2^{\mathrm{b}}$ \\
\hline
\end{tabular}

In each column, the means followed by different letters differ at $p \leq 0.05$.

Table 5 - Total production per tree and production efficiency in the Arbequina, Leccino and Maurino cultivars at the end of Oct of the fourth year after planting (means \pm standard error).

\begin{tabular}{lccc}
\hline Cultivar & Production/tree & Production/leaf area & Production/stem sectional area \\
\cline { 2 - 4 } Arbequina & $\mathrm{kg}$ & $0.43 \pm 0.12^{\mathrm{a}}$ & $0.24 \pm 0.07^{\mathrm{ab}}$ \\
Leccino & $2.31 \pm 0.20^{\mathrm{a}}$ & $0.54 \pm 0.08^{\mathrm{a}}$ & $0.19 \pm 0.06^{\mathrm{a}}$ \\
Maurino & $3.29 \pm 0.41^{\mathrm{b}}$ & $0.76 \pm 0.07^{\mathrm{b}}$ & $0.33 \pm 0.04^{\mathrm{b}}$ \\
\hline
\end{tabular}

In each column, the means followed by different letters differ at $p \leq 0.05$. 
other cultivars (Table 9). Leccino also had a higher content of stearic acid and lower linoleic acid than the other cultivars.

\section{Discussion}

Arbequina, as found in other olive growing areas (Tous et al., 2003 and 2010; Allalout et al., 2009 and 2011; Camposeo and Godini, 2010), also had low vigor in Central Italy, and, compared to Leccino and Maurino, seemed to invest more resources in forming the leaf surface area compared to woody mass. Maurino had vigor similar to that of Arbequina. Although Maurino grew taller, it had a more compact canopy than Arbequina and thus the volume of the canopy between the two cultivars was similar. Leccino, even in these early years of development, had high vigor, with higher growth, above all laterally, than the other cultivars.

Excessive lateral development is problematic in super high-density groves because it can make harvesting with a mechanical grape harvester difficult and the rubber beaters may damage the branches. Maurino seems an interesting cultivar not only for its limited vigor, but also for better light distribution in its canopy compared to the other two cultivars. The better light distribution in the canopy, as well as the higher leaf net photosynthetic rate found for Maurino by Proietti et al. (2012) in the same olive grove and year, should result in good total tree photosynthesis, despite the lower leaf surface area, as a result of better lighting in the internal portions (Ev-

Table 6 - Water and oil content, dry and fresh weight of olives in the Arbequina, Leccino and Maurino cultivars at the end of Oct (the data are the average of the third and fourth year after planting) (means \pm standard error).

\begin{tabular}{|c|c|c|c|c|}
\hline Cultivar & Water content & Oil content & Dry weight & Fresh weight \\
\hline & $\%$ & \% d.w. & & \\
\hline Arbequina & $43.68 \pm 0.81^{\mathrm{a}}$ & $35.99 \pm 1.1^{b}$ & $0.49 \pm 0.05^{\mathrm{a}}$ & $0.87 \pm 0.07^{a}$ \\
\hline Leccino & $45.83 \pm 1.22^{\mathrm{b}}$ & $32.87 \pm 0.97^{a}$ & $0.65 \pm 0.02^{b}$ & $1.20 \pm 0.04^{b}$ \\
\hline Maurino & $50.00 \pm 0.74^{c}$ & $36.31 \pm 0.82^{\mathrm{b}}$ & $0.50 \pm 0.04^{a}$ & $1.00 \pm 0.09^{a}$ \\
\hline
\end{tabular}

In each column, the means followed by different letters differ at $p \leq 0.05$.

Table 7 - Chemical characteristics of oils extracted from the Arbequina, Leccino and Maurino cultivars at the end of Oct (the data are the average of the third and fourth year after planting) (means \pm standard error).

\begin{tabular}{lccc}
\hline Cultivar & Phenol content & Acidity & Peroxide number \\
\hline & $\mathrm{ppm}$ & $\%$ & $\mathrm{meq}_{2} \mathrm{~kg}^{-1}$ \\
Arbequina & $565.2 \pm 32.1^{\mathrm{a}}$ & $0.28 \pm 0.03^{\mathrm{a}}$ & $6.50 \pm 0.9^{\mathrm{a}}$ \\
Leccino & $629.3 \pm 25.4^{\mathrm{b}}$ & $0.29 \pm 0.02^{\mathrm{a}}$ & $5.95 \pm 0.7^{\mathrm{a}}$ \\
Maurino & $650.1 \pm 23.2^{\mathrm{b}}$ & $0.26 \pm 0.03^{\mathrm{a}}$ & $6.88 \pm 0.4^{\mathrm{a}}$ \\
\hline
\end{tabular}

In each column, the means followed by different letters differ at $p \leq 0.05$.

Table 8 - Sensorial characteristics of oils extracted from the Arbequina, Leccino and Maurino cultivars at the end of Oct (the data are the average of the third and fourth year after planting) (means \pm standard error).

\begin{tabular}{lcccc}
\hline Cultivar & Fruity sensation & Bitter taste & Spicy taste & Quality total score \\
\hline & $0-5$ & $0-5$ & $0-5$ & $0-9$ \\
Arbequina & $3.2 \pm 0.4^{\mathrm{a}}$ & $2.7 \pm 0.5^{\mathrm{a}}$ & $2.6 \pm 0.4^{\mathrm{a}}$ & $8.2 \pm 0.7^{\mathrm{a}}$ \\
Leccino & $3.2 \pm 0.3^{\mathrm{a}}$ & $2.4 \pm 0.8^{\mathrm{a}}$ & $2.3 \pm 0.5^{\mathrm{a}}$ & $8.1 \pm 0.5^{\mathrm{a}}$ \\
Maurino & $3.6 \pm 0.5^{\mathrm{a}}$ & $3.1 \pm 0.7^{\mathrm{a}}$ & $2.9 \pm 0.3^{\mathrm{a}}$ & $8.6 \pm 0.4^{\mathrm{a}}$ \\
\hline
\end{tabular}

For each column, the means followed by different letters differ at $p \leq 0.05$.

Table 9 - The fatty acid composition of oils extracted from the Arbequina, Leccino and Maurino cultivars at the end of Oct (the data are the average of the third and fourth year after planting) (means \pm standard error).

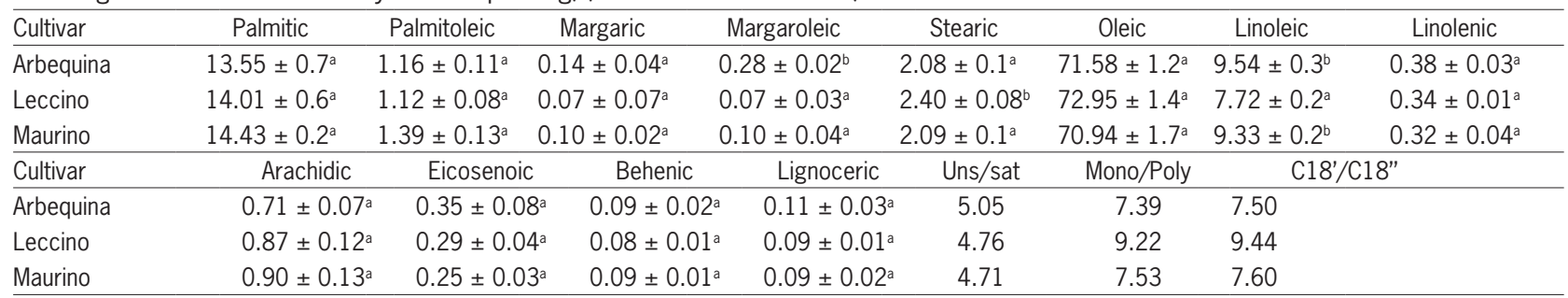

For each parameter, the means followed by different letters differ at $p \leq 0.05$. 
ans, 1975; Daie, 1985; Tichá et al., 1985; Ceulemans and Saugier, 1991; Proietti et al., 1994). This could be one of the reasons for the higher production efficiency (amount of production per unit of leaf area) in Maurino compared to the other cultivars.

The better distribution of light in the canopy of Maurino may be attributed to a lower amount of empty spaces in the canopy compared to Arbequina and above all to Leccino as well as a different leaf orientation in the space, which tends more towards the vertical. In this way Maurino could more efficiently exploit the space by limiting leaf overlapping and thus mutual shading among leaves is significantly reduced. This is very interesting for super high-density olive groves due to the low space available for each tree. Indeed, Maurino, despite having a higher LAI than Leccino, had better lighting inside the canopy which can only be partly attributed to the lower canopy size and thus to its better surface/ volume ratio.

The higher palisade parenchyma found in Maurino, both in absolute terms and in terms of percentage, and the large exposed lateral surface area of the palisade parenchyma cells could be correlated with its photosynthetic capacity (Chartzoulakis et al., 1999). This could explain, at least in part, the higher net photosynthesis per unit leaf area found during the growing season in this cultivar with respect to Arbequina in the same olive grove and same year as observed by Proietti et al. (2012).

The larger amount of intercellular space and the larger exposed lateral surface area suggest a greater gas exchange facility in the palisade tissue in Maurino than in the other two cultivars. In addition, the higher value obtained in Maurino by multiplying the number of stomata per $\mathrm{mm}^{2}$ by the average length of their guard cells could help explain the higher leaf photosynthetic rate reported for this cultivar, according to Kundu and Tigerstedt (1998) who found a positive correlation between the stomatal density and the length of the guard cells in Azadirachta indica A. Juss., and to Bosabadilis and Kofidis (2002) who found that the number and size of stomata are important for leaf gas exchange in olive. Also the slightly higher leaf ADM of Maurino may partially explain the higher leaf photosynthetic rate compared to Leccino.

The production of Arbequina was less than the other two cultivars and lower or similar to those reported in the literature for super high-density olive groves of the same age in other areas (León et al., 2007; Camposeo and Godini, 2010; Tous et al., 2012). All cultivars produced oils with medium-high fruity values and good chemical and nutritional quality. Maurino oil was slightly more fruity, bitter and pungent than those of Arbequina and Leccino. Total phenol content of Arbequina was lower than those of Maurino and Leccino, but higher than that reported in the literature for this cultivar in warmer areas (Camposeo and Godini, 2010).

The identification of some local/national cultivars that can adapt to super high-density olive groves could eliminate some problems associated with this kind of cultivation. The results from this study are useful for projecting future studies and also for evaluating the potential production of super high-density olive groves in new environments.

\section{Conclusions}

Arbequina and Maurino are interesting cultivars for super high-density olive groves in central Italy. Arbequina has low vigor and thus little development in height and width, and has a high leaf/wood ratio. Maurino has low vigor, although with a greater tendency to grow in height, and a rather compact vegetative habitus and is characterized by good light distribution in the canopy. A satisfactory response to super high-density olive groves was expected for Arbequina, while for Maurino, the results are very interesting.

\section{Acknowledgements}

This research was supported by the Italian Ministero dell'Istruzione, dell'Università e della Ricerca - PRIN 2008 Project "Biological processes and environmental factors involved in the vegetative growth, fruiting and quality of oil control in super-intensive olive planting".

\section{References}

Allalout, A.; Krichène, D.; Methenni, K.; Taamalli, A.; Oueslati, I.; Daoud, D.; Zarrouk, M. 2009. Characterization of virgin olive oil from Super Intensive Spanish and Greek varieties grown in northern Tunisia. Scientia Horticulturae 120: 77-83.

Allalout, A.; Krichène, D.; Methenni, K.; Taamalli, A.; Daoud, D.; Zarrouk, M. 2011. Behavior of super-intensive Spanish and Greek olive cultivars grown in northern Tunisia. Journal of Food Biochemistry 35: 27-43.

Bosabadilis, A.M.; Kofidis, G. 2002. Comparative effects of drought stress on leaf anatomy of two olive cultivars. Plant Science 163: 375-379.

Camposeo, S.; Ferrara, G.; Palasciano, M.; Godini, A. 2008. Varietal behaviour according to the superintensive oliveculture training system. Acta Horticulturae 791: 271-274.

Camposeo, S.; Godini, A. 2010. Preliminary observations about the performance of 13 varieties according to the super high density oliveculture training system in Apulia (southern Italy). Advances in Horticultural Science 24: 16-20.

Ceulemans, R.J.; Saugier, B. 1991. Photosynthesis. p. 21-50. In: Raghavendra, A.S., eds. Physiology of trees. Wiley, New York, NY, USA.

Chartzoulakis, K.; Patakas, A.; Bosabalidis, A.M. 1999. Changes in water relations, photosynthesis and leaf anatomy induced by intermittent drought in two olive cultivars. Environmental and Experimental Botany 42: 113-120.

Cherbiy-Hoffmann, S.U.; Hallb, A.J.; Rousseauxa, M.C. 2013. Fruit, yield, and vegetative growth responses to photosynthetically active radiation during oil synthesis in olive trees. Scientia Horticulturae 150: 110-116. 
Daie, J. 1985. Carbohydrate partitioning and metabolism in crops. Horticultural Reviews 7: 69-108.

De La Rosa, D.; León, R.; Guerrero, L.; Rallo, N.; Barranco, L. 2007. Preliminary results of an olive cultivar trial at high density. Australian Journal of Agricultural Research 58: 392395.

Evans, L.T. 1975. The physiological basis of crop yield. p. 327-355. In: Evans, L.T., eds. Crop physiology. Cambridge University Press, London, UK.

Food and Agriculture Organization. [FAO]. FAOSTAT. 2012. FAO, Rome, Italy. Available at: http://faostat.fao.org/ [Accessed Mar. $18,2014]$

Godini, A.; Vivaldi, G.A.; Camposeo, S. 2011. Olive cultivars field-tested in super-high -density system in southern Italy. California Agriculture 65: 39-40.

Kundu, S.K.; Tigerstedt, P.M.A. 1998. Variation in net photosynthesis, stomatal characteristics, leaf area and wholeplant phytomass production among ten provenance of neem (Azadirachta indica). Tree Physiology 19: 47-52.

León, L.; De La Rosa, R.; Rallo, L.; Guerrero, N.; Barranco, D. 2007. Influence of spacing on the initial production of hedgerow 'Arbequina' olive orchards. Spanish Journal of Agricultural Research 5: 554-558.

Lichtenthaler, H.K.; Wellburn, A.R. 1983. Determinations of total carotenoids and chlorophylls a and $\mathrm{b}$ of leaf extracts in different solvents. Biochemical Society Transactions 11: 591-592.

Proietti, P.; Tombesi, A.; Boco, M. 1994. Influence of leaf shading and defoliation on oil synthesis and growth of olive fruits. Acta Horticulturae 356: 272-277.

Proietti, P.; Nasini, L.; Ilarioni, L. 2012. Photosynthetic behavior of Spanish Arbequina and Italian Maurino olive (Olea europaea L.) cultivars under super-intensive grove conditions. Photosynthetica 50: 239-246.
Proietti， P.; Nasini, L.; Ilarioni, L.; Balduccini, A.M. 2011. Photosynthesis and vegetative-productive activities of the olive cultivars 'Arbequina', 'Leccino' and 'Maurino' in a very high density olive grove in central Italy. Acta Horticulturae 924: 111116.

Reale, L.; Sgromo, C.; Ederli, L.; Pasqualini, S.; Orlandi, F.; Fornaciari, M.; Ferranti, F.; Romano, B. 2009. Morphological and cytological development and starch accumulation in hermaphrodite and staminate flowers of olive (Olea europaea L.). Sexual Plant Reproduction 22: 109-119.

Schneider, D.; Goldway, M.; Birger, R.; Stern, R.A. 2012. Does alteration of 'Koroneiki' olive tree architecture by uniconazole affect productivity? Scientia Horticulturae 139: 79-85.

Tichá, I.; atský, J.; Hodá ová, D.; Pospíšilová, J.; Kaše, M.; Šesták, Z. 1985. Gas exchange and dry matter accumulation during leaf development. p. 157-216. In: Šesták, Z., ed. Photosynthesis during leaf development. Springer, Berlin, Germany.

Tombesi, A.; Boco, M.; Pilli, M.; Farinelli, D. 2000. Influenza della potatura sulla raccolta meccanica delle olive con vibratori di tronco. Rivista di Frutticoltura e di ortofloricoltura 10: 69-73.

Tous, J.; Romero, A.; Plana, J. 2003. Plantaciones superintensivas en olivar Comnportamiento de 6 variedades. Agricultura 851: 346-350.

Tous, J.; Romero, A.; Hermoso, J.F. 2010. New trends in olive orchard design for continuous mechanical harvesting. Advances in Horticultural Science 24: 43-52.

Tous, J. 2012. Olive production systems and mechanization. Acta Horticulturae 924: 169-184. 